\title{
TNF-stimulated MAP kinase activation mediated by a Rho family GTPase signaling pathway
}

\author{
Shashi Kant, ${ }^{1,2}$ Wojciech Swat, ${ }^{3}$ Sheng Zhang, ${ }^{4}$ Zhong-Yin Zhang, ${ }^{4}$ Benjamin G. Neel, ${ }^{5}$ \\ Richard A. Flavell, ${ }^{6,7}$ and Roger J. Davis ${ }^{1,2,8}$ \\ ${ }^{1}$ Howard Hughes Medical Institute, University of Massachusetts Medical School, Worcester, Massachusetts 01605, USA; ${ }^{2}$ Program \\ in Molecular Medicine, University of Massachusetts Medical School, Worcester, Massachusetts 01605, USA; ${ }^{3}$ Department of \\ Pathology and Immunology, Washington University School of Medicine, St. Louis, Missouri 63110, USA; ${ }^{4}$ Department of \\ Biochemistry and Molecular Biology, Indiana University School of Medicine, Indianapolis, Indiana 46202, USA; ${ }^{5}$ Ontario \\ Cancer Institute, Toronto, Ontario M5G 1L7, Canada; ${ }^{6}$ Howard Hughes Medical Institute, Yale University School of Medicine, \\ New Haven, Connecticut 06520, USA; ${ }^{7}$ Department of Immunobiology, Yale University School of Medicine, New Haven, \\ Connecticut 06520, USA
}

The biological response to tumor necrosis factor (TNF) involves activation of MAP kinases. Here we report a mechanism of MAP kinase activation by TNF that is mediated by the Rho GTPase family members Rac/Cdc42. This signaling pathway requires Src-dependent activation of the guanosine nucleotide exchange factor Vav, activation of Rac/Cdc42, and the engagement of the Rac/Cdc42 interaction site (CRIB motif) on mixed-lineage protein kinases (MLKs). We show that this pathway is essential for full MAP kinase activation during the response to TNF. Moreover, this MLK pathway contributes to inflammation in vivo.

[Keywords: MAP kinase; MLK; mixed-lineage protein kinase; TNF]

Supplemental material is available for this article.

Received June 13, 2011; revised version accepted August 26, 2011.

The tumor necrosis factor (TNF) signaling pathway is established to be a target for the development of effective strategies for the treatment of human inflammatory diseases (Feldmann 2002). Knowledge of the mechanism of TNF signaling is therefore important for the design of novel therapeutic approaches. Biological responses to TNF involve activation of signal transduction pathways, including MAP kinases and NF-кB (Karin 2005).

TNF recruits TRADD, TRAF2, and RIP1 to the cytoplasmic domain of TNF receptor 1 (Micheau and Tschopp 2003). This complex initiates signal transduction mediated by NF-кB. Activation of the NF-кB pathway requires ubiquitin-mediated activation of the protein kinase TAK1 (Skaug et al. 2009). Studies of Tak $1^{-/-}$murine cells confirm that TAK1 is essential for TNF-induced activation of IкB kinase $\beta(\operatorname{IKK} \beta)$ and the subsequent degradation of IкB $\alpha$, a critical step in NF-кB signaling (Sato et al. 2005; Shim et al. 2005). The TAK1 protein kinase therefore plays a central role in TNF-mediated activation of NF-кB.

${ }^{8}$ Corresponding author.

E-mail roger.davis@umassmed.edu.

Article is online at http://www.genesdev.org/cgi/doi/10.1101/gad.17224711. Freely available online through the Genes \& Development Open Access option.
TNF-stimulated MAP kinase activation is also mediated by the TRADD/TRAF2/RIP1 complex that is recruited to the cytoplasmic domain of TNF receptor 1 (Micheau and Tschopp 2003). Several members of the MAP kinase kinase kinase (MAP3K) group (e.g., ASK1 [Ichijo et al. 1997; Nishitoh et al. 1998; Tobiume et al. 2001], MEKK1 [Xia et al. 2000], mixed-lineage protein kinase 3 [MLK3] [Sathyanarayana et al. 2002; Chadee and Kyriakis 2004; Brancho et al. 2005; Korchnak et al. 2009; Sondarva et al. 2009], TAK1 [Sato et al. 2005; Shim et al. 2005], and TPL2 [Das et al. 2005]) have been implicated in TNF-induced MAP kinase activation. The relative contribution of these MAP3Ks to TNF-stimulated MAP kinase activation is unclear. The roles of individual MAP3Ks may reflect differences between TNF-responsive cells and/or differences between separate MAP kinase pathways. These MAP kinase pathways include the cJun N-terminal kinase (JNK), p38 MAP kinase, and extracellular signal-regulated kinases (ERKs). Each of these MAP kinases is activated by different MAP kinase kinase (MAP2K) isoforms. Thus, JNK activation requires MKK7 and cooperative signaling by MKK4 (Tournier et al. 2001), TNF-stimulated activation of p38 MAP kinase requires both MKK3 and MKK6 (Brancho et al. 2003), and ERK activation is mediated by MKK1 and MKK2 (Robinson and Cobb 1997). These 
pathways lead to ERK, JNK, and p38 MAP kinase activation by a dual phosphorylation (Thr and Tyr) mechanism.

It is established that TNF causes activation of Rho family GTPase proteins-including Rac/Cdc42 (WojciakStothard et al. 1998; Kim et al. 1999; Puls et al. 1999; Hanna et al. 2001) — that may contribute to actin cytoskeleton reorganization (Wojciak-Stothard et al. 1998) and the production of reactive oxygen species (Kim et al. 2007; Yazdanpanah et al. 2009). The purpose of this study was to examine whether the TNF-stimulated Rac/Cdc42 pathway might contribute to MAP kinase activation (Coso et al. 1995; Minden et al. 1995). We report that TNF can activate a PTPN1/Src/Vav pathway that causes MLKdependent activation of MAP kinases.

\section{Results}

Requirement of the Rac/Cdc42 interaction site (CRIB motif) on MLK3 for TNF-stimulated MAP kinase activation

Treatment of primary murine fibroblasts (MEFs) (Fig. 1A) and bone marrow-derived macrophages (BMDMs) (Fig. 1B) with TNF causes rapid activation of Rac and Cdc42. We examined whether this TNF-stimulated Rac/Cdc42 pathway might contribute to MAP kinase activation (Coso et al. 1995; Minden et al. 1995) by binding to the Rac/ Cdc42 interaction site (CRIB motif) on MLK3 (Teramoto et al. 1996). To test this hypothesis, we investigated the effect of point mutations (Ile ${ }^{492}$ and Ser ${ }^{493}$ replaced with Ala) that disrupt the CRIB motif and prevent Rac/Cdc42dependent activation of MLK3 (Bock et al. 2000). Mice with germline point mutations in the Mlk3 gene were established $\left(M I k 3^{\triangle C R I B / \triangle C R I B}\right.$ mice $)$ and primary cultures of MEFs were prepared (Fig. 1C-F). We found similar TNFstimulated MAP kinase activation in control $\left(\mathrm{Mlk}^{+/+}\right)$and mutant $\left(M I k 3^{\triangle C R I B / \triangle C R I B}\right)$ MEFs (data not shown). This observation may reflect a redundant role of MLK3 in TNFmediated signal transduction.

Gene expression analysis demonstrated that MEFs primarily express MLK2 and MLK3 (Supplemental Fig. S1). We therefore employed $M 1 k 2^{-/-}$mice (Supplemental Fig. S2), Mlk3 ${ }^{-/-}$mice (Brancho et al. 2005), and compound mutant $M 7 k 2^{-/-} M l k 3^{-/-}$mice (Supplemental Fig. S2) to prepare MEFs. Control studies demonstrated that MLK deficiency did not alter cell morphology or proliferation (Fig. 2). Deficiency of MLK2 or MLK3 caused only minor changes in TNF-stimulated MAP kinase activation (Supplemental Fig. S3), but TNF-stimulated MAP kinase activation in Mlk2 ${ }^{-1-} \mathrm{Mlk3}^{-/-}$MEFs was markedly reduced (Fig. 1G). The reduced TNF-stimulated MAP kinase activation detected in $\mathrm{Mlk}^{-1-} \mathrm{Mlk} 3^{-/-}$ MEFs was not associated with altered TNF-stimulated activation of IKK $\beta$ or degradation of $\operatorname{I\kappa B} \alpha$ (Fig. 1G). Thus, the MLK pathway (mediated by redundant functions of MLK2 and MLK3) is required for maximal TNFstimulated MAP kinase activation, but is not required for TNF-stimulated activation of the NFkB pathway. This selective requirement of MLK2/3 for MAP kinase activation was also observed in studies of $M l k 2^{-/-}$
Mlk3 $^{-/-}$BMDMs treated with TNF or lipopolysaccharide (LPS) (Fig. 1H).

MLK2 and MLK3 have partially redundant functions (Fig. 1G,H). We therefore re-examined the effect of the MLK3 CRIB mutation in a MLK2-deficient genetic background. This analysis demonstrated that TNF-stimulated MAP kinase activation in Mlk2 ${ }^{-/-}$Mlk $3^{\Delta \mathrm{CRIB} / \Delta \mathrm{CRIB}} \mathrm{MEFs}$ was markedly suppressed (Fig. 1I). In contrast, no difference in TNF-stimulated IкB $\alpha$ degradation was detected

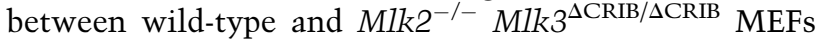
(Fig. 1I). These data confirm that the MLK pathway contributes to TNF-stimulated MAP kinase activation, but not TNF-stimulated NF- $\kappa$ B activation.

To test whether Rac-mediated activation of MAP kinase is mediated by the MLK pathway, we expressed constitutively activated Rac in wild-type MEFs, Mlk2 ${ }^{-/-} \mathrm{Mlk}^{-/-}$ MEFs, and Mlk2 $2^{-/-}$Mlk3 $3^{\Delta \mathrm{CRIB} / \Delta \mathrm{CRIB}}$ MEFs (Supplemental Fig. S4). Activated Rac caused JNK activation in wild-type MEFs, but did not cause JNK activation in MEFs with MLK pathway defects. These data demonstrate that the MLK pathway is an essential mediator of Rac signaling.

The low-level TNF-stimulated MAP kinase activation detected in $\mathrm{Mlk2}^{-1-} \mathrm{Mlk3}^{-/-}$MEFs and $\mathrm{Mlk}^{-1-}$ Mlk3 ${ }^{\Delta \mathrm{CRIB} / \triangle \mathrm{CRIB}}$ MEFs (Fig. 1G-I) may be mediated by TAK1. Indeed, TNF can cause partial MAP kinase activation in Tak1 $1^{-1-}$ MEFs (Fig. 3A), and RNAi-mediated knockdown of TAK1 in Mlk2 $2^{-/-}$Mlk3 $^{-/-}$MEFs strongly reduced TNF-stimulated MAP kinase activation (Fig. 3B-D). Together, these data indicate that TNF-stimulated MAP kinase activation is mediated by the coordinated activation of at least two signaling pathways (MLK2/3 and TAK1).

\section{Vav guanine nucleotide exchange factors mediate TNF signaling}

The suppression of TNF-stimulated MAP kinase activation caused by mutation of the MLK3 CRIB motif (Fig. 1) indicates that Rac/Cdc42 may mediate TNF-induced MAP kinase activation. However, the mechanism that accounts for TNF-stimulated Rac/Cdc42 activation is unclear. To identify TNF-regulated guanine nucleotide exchange factors (RhoGEFs), we isolated proteins that interact with a nucleotide-free form of Rac ( $\operatorname{Racl}^{\mathrm{Gly} 15 \mathrm{Ala}}$, a mimic of the guanine nucleotide transition state) from control and TNF-treated cells using affinity chromatography (Garcia-Mata et al. 2006). Vav was identified as a TNF-activated RhoGEF (Fig. 4A). In contrast, the RhoGEF isoforms GEFT and TIAM1 were not activated by TNF (Fig. 4A). To test whether Vav contributes to TNF-stimulated Rac activation, we examined Rac activation in wild-type and Vav1/2/3-deficient primary BMDMs (Fig. 4B). This analysis demonstrated that Vav contributes to TNF-stimulated Rac activation (Fig. 4B).

\section{TNF causes tyrosine phosphorylation and activation of $\mathrm{Vav}$}

It is established that tyrosine phosphorylation represents a major mechanism of Vav regulation (Swat and Fujikawa 2005). Indeed, TNF caused increased Vav tyrosine phosphorylation (Fig. 4C). Candidate tyrosine kinases that might mediate this tyrosine phosphorylation include 
A

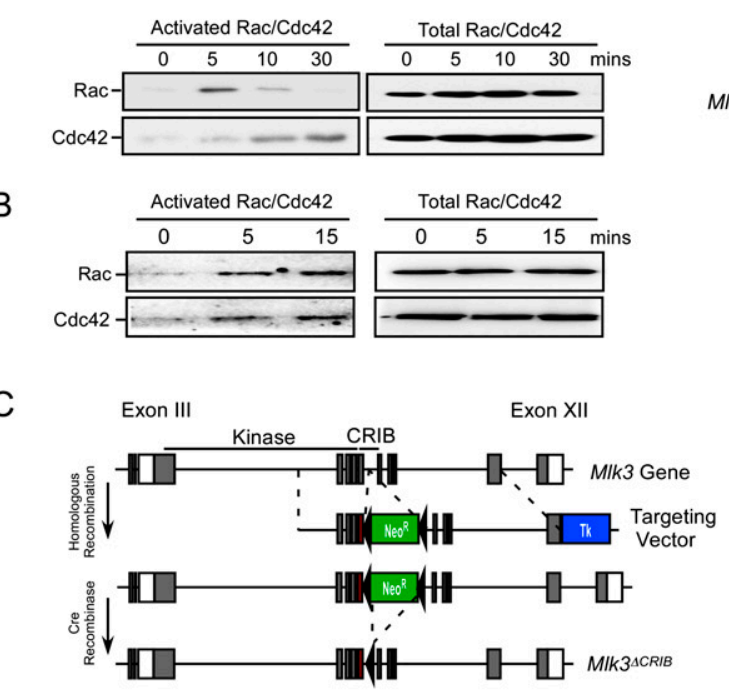

D

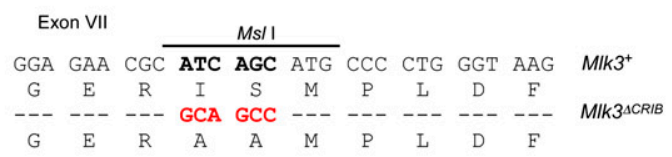

$\mathrm{H}$

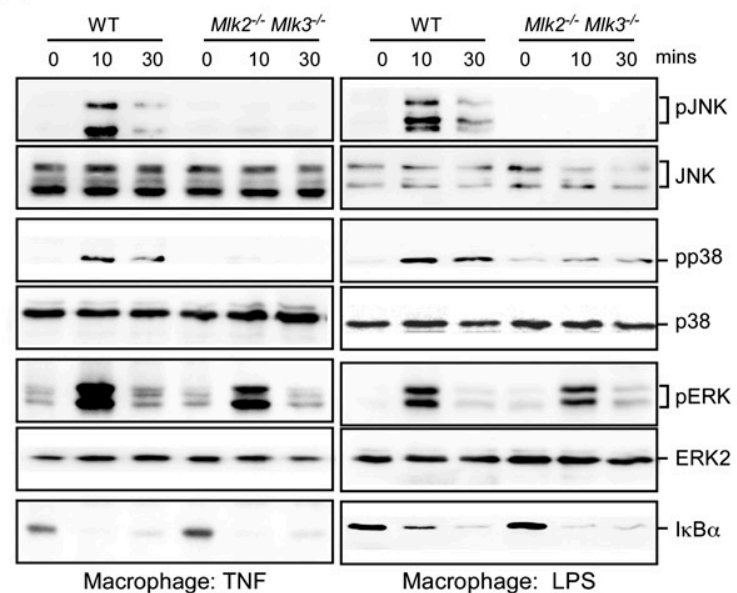

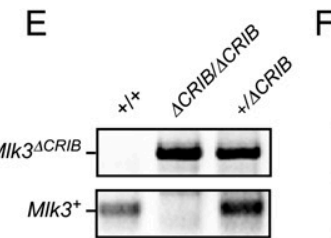

$\mathrm{F}$

G

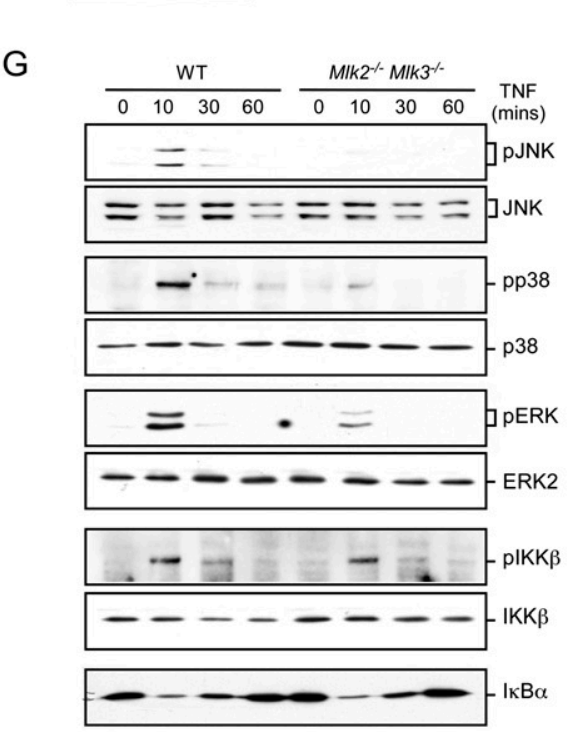

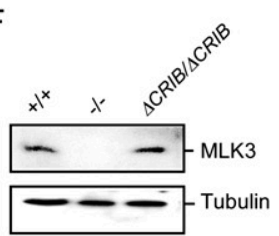

I

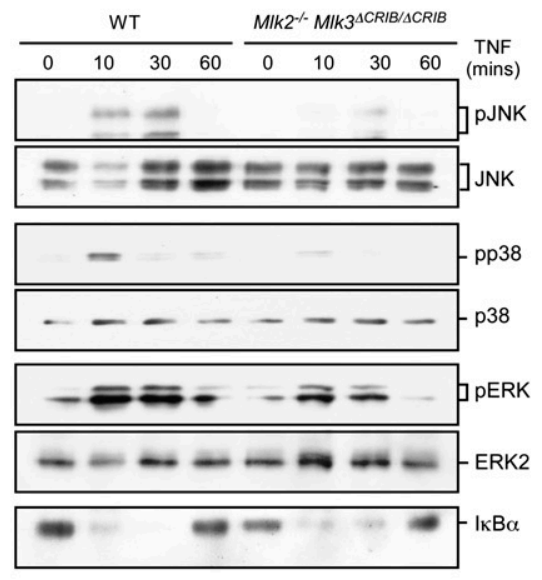

Figure 1. TNF causes activation of a Rac/Cdc42-MLK signal transduction pathway. $(A, B)$ MEFs $(A)$ or BMDMs $(B)$ were treated without or with $10 \mathrm{ng} / \mathrm{mL}$ TNF $\alpha$. Activated (GTP-loaded) Rac/Cdc42 was isolated and quantitated by immunoblot analysis. The amount of Rac/Cdc42 in cell lysates was measured by immunoblot analysis. $(C)$ The structure of the Mlk3 genomic locus and the targeting vector are illustrated. Homologous recombination causes the replacement of Mlk3 exon VII with a mutated form of exon VII together with the insertion of a floxed $N e o^{R}$ cassette. The floxed $N e o^{R}$ cassette was excised using Cre recombinase. $(D)$ The point mutations in exon VII created by the targeting vector are illustrated. The nucleotide changes cause the elimination of an MsII restriction site and the introduction of two amino acid substitutions (Ile492Ala and Ser493Ala) that disrupt the MLK3 CRIB domain. (E) Genomic DNA from wild-type, $M l k 3^{+/ \triangle C R I B}$, and $M I k 3^{4 C R I B / \triangle C R I B}$ mice was examined by PCR analysis to detect the wild-type and mutant Mlk3 alleles. (F) Extracts prepared from wild-type (WT), Mlk $3^{-1-}$, and Mlk $3^{\Delta C R I B / \triangle C R I B}$ MEFs were examined by immunoblot

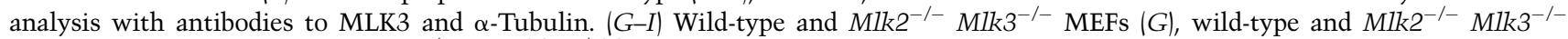
BMDMs $(H)$, or wild-type and $M l k 2^{-/-}$Mlk $3^{\Delta C R I B / \triangle C R I B}$ MEFs $(I)$ were treated without or with $10 \mathrm{ng} / \mathrm{mL}$ TNF or $100 \mathrm{ng} / \mathrm{mL}$ LPS. MAP kinase and IKK $\beta$ activation and the degradation of IкB $\alpha$ were examined by immunoblot analysis.

members of the Src family (e.g., Src, Fyn, and Yes). We found that TNF did not cause Vav tyrosine phosphorylation in $\mathrm{Src}^{-/-} \mathrm{Fyn}^{-1-} \mathrm{Yes}^{-/-}$fibroblasts, but complementation analysis demonstrated that re-expression of Src was sufficient to restore TNF-stimulated Vav tyrosine phosphorylation (Fig. 4D). Both Vav-deficient and Src/Fyn/Yesdeficient cells exhibited defects in TNF-stimulated activation of MAP kinases (Fig. 4E,F). Together, these data 
A

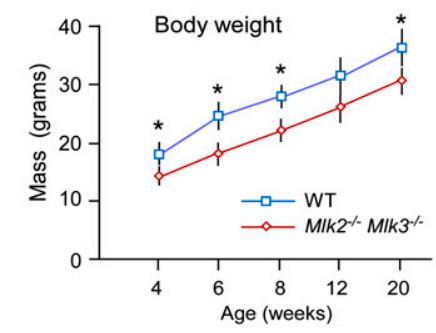

C

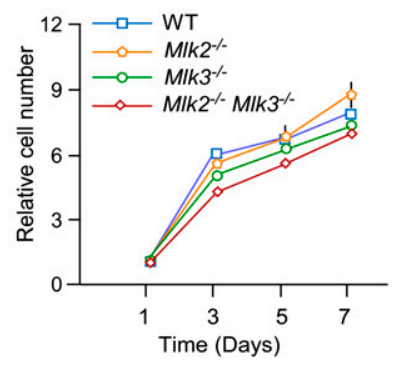

B

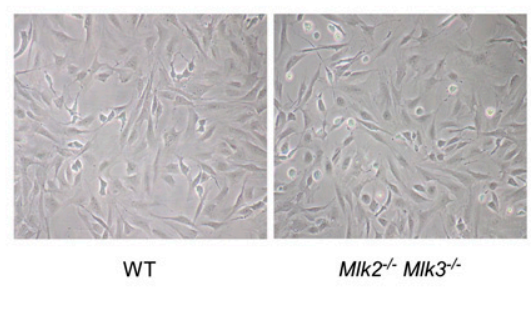

D

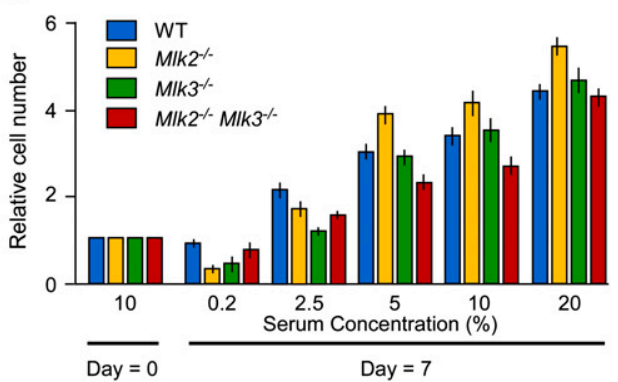

Figure 2. The effect of MLK2 and MLK3 deficiency on growth. $(A)$ The body mass of male wild-type (WT) and Mlk2 $2^{-/-} M l k 3^{-/-}$mice was measured at different time intervals (mean $\pm \mathrm{SD}$; $n=8$ ). Statistically significant differences are indicated. $\left(^{\star}\right) P<0.05$. (B) Wild-type and Mlk2 $2^{-/-}$ Mlk3 $^{-1-}$ MEFs were examined by phase-contrast microscopy. $(C)$ The proliferation of wild-type, $\mathrm{Mlk2}^{-1-}, \mathrm{Mlk3}^{-/-}$, and Mlk2 ${ }^{-1-} \mathrm{Mlk3}^{-/-}$MEFs during culture for $7 \mathrm{~d}$ was examined by plating $2.5 \times 10^{4}$ MEFs in 11-mm wells using Dulbecco's modified Eagle's medium supplemented with $10 \%$ fetal calf serum. Relative cell numbers were measured by staining with crystal violet (mean \pm SD; $n=6$ ). No significant differences between wild-type and MLK-deficient MEFs were detected. $P>0.05$. (D) MEFs were incubated for 0 or $7 \mathrm{~d}$ in Dulbecco's modified Eagle's medium supplemented with different amounts of fetal bovine serum. Relative cell numbers were measured by staining with crystal violet (mean $\pm \mathrm{SD} ; n=6$ ). No significant differences between wild-type and MLK-deficient MEFs were detected. $P>0.05$. demonstrate that a Src/Vav pathway contributes to TNFstimulated MAP kinase activation.

\section{Requirement of PTPN1 for TNF-stimulated Rac activation}

Src family protein kinases have been previously implicated in TNF-stimulated MAP kinase activation mediated by TRAF2-associated tyrosine phosphatases (van Vliet et al. 2005). This pathway mediates TNF-stimulated MAP kinase activation, but not TNF-stimulated NFкB activation (van Vliet et al. 2005). The related tyrosine phosphatases PTPN1 and PTPN2 can cause opposite actions on Src family kinase activity by selectively dephosphorylating the inhibitory C-terminal site (PTPN1) or the activating T-loop site (PTPN2) of tyrosine phosphorylation (van Vliet et al. 2005). Increased PTPN1 and/or decreased PTPN2 function may therefore contribute to TNF-stimulated MAP kinase activation. We found that TNF caused decreased tyrosine phosphorylation of the C-terminal site of inhibitory tyrosine phosphorylation on Src (pY-527) in BMDMs isolated from control mice, but not from Ptpn $1^{-/-}$ mice (Fig. 5A). Moreover, TNF-stimulated Rac activation (Fig. 5B) and MAP kinase activation (Fig. 5C) was suppressed by PTPN1 deficiency. To confirm this observation, we examined the effect of selective small molecule inhibitors of PTPN1 and PTPN2. We found that inhibition of PTPN1 suppressed TNF-stimulated MAP kinase activation and that PTPN2 inhibition augmented TNF-stimulated MAP kinase activation (Fig. 5D). These data demonstrate that tyrosine phosphatases contribute to the regulation of TNF-stimulated MAP kinase activation.

\section{The MLK and TAK1 pathways mediate different TNF biological responses}

The results of this study demonstrate that full activation of MAP kinases caused by TNF requires a Rac/Cdc42 signaling pathway that is mediated by Src-induced Vav activation and engagement of MLK protein kinases. To examine the contribution of this pathway to TNF signaling, we compared the response of control and MLKdeficient MEFs to treatment with TNF, including the expression of inflammatory cytokines and cell death. We found that TNF-treated Mlk2 ${ }^{-/-}$Mlk $^{-/-}$MEFs secrete markedly less interleukin 6 (IL6) than wild-type cells (Fig. 6A), consistent with reduced MAP kinase activation in MLK-deficient cells (Fig. 1G,H). Previous studies have established that the ERK, JNK, and p38 MAP kinase pathways can contribute to Il6 gene expression (Tuyt et al. 1999; Kim et al. 2004; Ventura et al. 2006), but increased IL6 expression caused by the Vav pathway is primarily mediated by JNK (Song et al. 1999). We found that Mlk2 $2^{-/-} M_{1 k 3^{-/-}}$MEFs (like wild-type MEFs) activate the NF-кB survival pathway (Fig. 1G) and exhibit resistance to the cytotoxic effects of TNF (Fig. 6B,C). In contrast, Tak1 ${ }^{-/-}$cells were sensitive to TNF-mediated cytotoxicity (Fig. 6B,C) and failed to activate the NF-кB pathway (Fig. 3A). Together, these data demonstrate that the MLK and TAK1 pathways mediate different TNFdependent cellular responses.

\section{The MLK pathway contributes to inflammation in vivo}

To test whether the MLK pathway can mediate inflammation, we examined the effect of MLK deficiency on the response of mice to endotoxin exposure. Treatment of wild-type mice with LPS caused increased expression of inflammatory cytokines (e.g., TNF $\alpha$ ) and chemokines (e.g., CCL3 and CCL5) in blood (Fig. 7A). These effects of LPS were suppressed in MLK-deficient mice $\left(\mathrm{Mlk}^{-{ }^{-/}}\right.$ $M 7 k 3^{-1-}$ ) and mice with MLK CRIB motif mutation $\left(M 1 k 2^{-1-} M 1 k 3^{\triangle C R I B / \triangle C R I B}\right)$ (Fig. 7A). Control studies using in vitro cultures of BMDMs confirmed that the MLK pathway is required for LPS-stimulated cytokine 
A

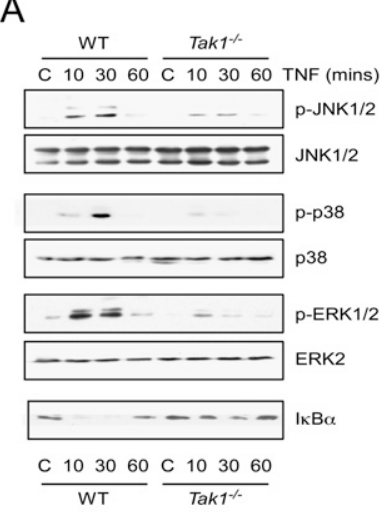

C

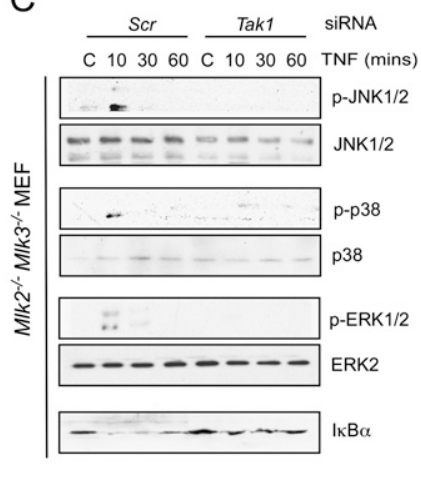

B

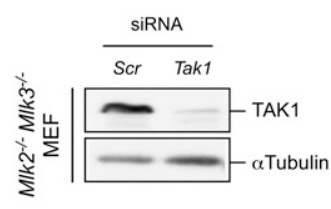

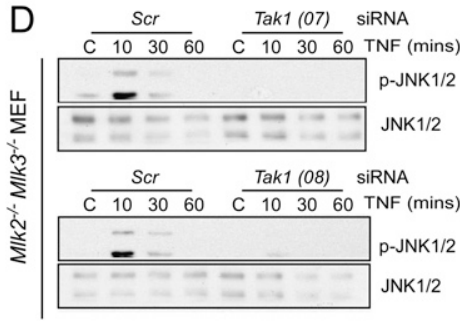

Figure 3. Residual MAP kinase activation in MLK-deficient MEFs is mediated by TAK1. (A) Wild-type (WT) and Tak1 ${ }^{-1-}$ MEFs were treated without or with TNF $\alpha(10 \mathrm{ng} / \mathrm{mL})$. The activation of MAP kinases and the degradation of IкB $\alpha$ was examined by immunoblot analysis. $(B, C) \mathrm{Mlk2}^{-1-} \mathrm{Mlk3}^{-/-} \mathrm{MEFs}$ were transfected with control (Scr) siRNA or Tak1 siRNA (72 h). Transfection assays were performed using DharmaFECT 3 reagent with ON-TARGET plus Nontargeting Pool D-001810-10 for control or ON-TARGET plus SMART pool L-040718-00 for Tak1 (MAP3K7) siRNA (Thermo Scientific). (B) The expression of TAK1 and $\alpha$-Tubulin was examined by immunoblot analysis. $(C)$ MAP kinase activation and the degradation of $\mathrm{I}_{\kappa} \mathrm{B} \alpha$ in response to treatment with $\mathrm{TNF} \alpha(10 \mathrm{ng} / \mathrm{mL})$ were examined by immunoblot

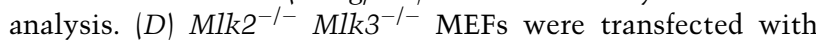
scrambled (Scr) siRNA or Tak1 siRNA (72 h). The MEFs were treated without or with $10 \mathrm{ng} / \mathrm{mL}$ TNF $\alpha$. Protein extracts were examined by immunoblot analysis by probing with antibodies to JNK1/2 and phospho-JNK. The siRNA for Tak1 were ONTARGET plus siRNA J-040718-07 (top panel) and J-040718-08 (bottom panel).

and chemokine expression (Fig. 7B). Together, these data establish that the MLK pathway contributes to inflammation.

\section{Discussion}

The biological response to TNF is mediated by the integrated actions of several signaling pathways. The NF- $\mathrm{kB}$, MAP kinase, and caspase pathways are key mediators of the TNF response. TNF can also activate Rho family GTPases, including Rac/Cdc42 (Wojciak-Stothard et al. 1998; Kim et al. 1999; Puls et al. 1999; Hanna et al. 2001). Previous studies have established that Rac/Cdc42 may contribute to the effects of TNF on actin cytoskeleton reorganization (Wojciak-Stothard et al. 1998) and the production of reactive oxygen species (Kim et al. 2007; Yazdanpanah et al. 2009). Rac/Cdc42 therefore plays an important role in the cellular response to TNF. Our study demonstrates that TNF-stimulated Rac/Cdc42 activation also contributes to MAP kinase regulation (Fig. 1).

The mechanism of TNF-stimulated Rac/Cdc42 activation requires Vav (Fig. 4B), a guanine nucleotide exchange factor that is activated by tyrosine phosphorylation (Crespo et al. 1997; Han et al. 1997) and can activate both Rac and Cdc42 (Abe et al. 2000; Liu and Burridge 2000). TNF causes tyrosine phosphorylation and activation of Vav by Src family protein kinases (Fig. 4C,D) that are activated by dephosphorylation on the inhibitory C-terminal site of tyrosine phosphorylation (Fig. 5A). Src activation requires the protein tyrosine phosphatase PTPN1 (Fig. 5A). The related phosphatase PTPN2 can oppose the activation of Src and functions to suppress TNF-stimulated MAP kinase activation (van Vliet et al. 2005). The balance of PTPN1 and PTPN2 can therefore determine the activation state of Src and, consequently, the extent of Vav-mediated Rac activation. PTPN2 interacts with TNF signaling complexes containing TRAF2 (van Vliet et al. 2005). The mechanism of TNF signaling may therefore be mediated by sequestration of the inhibitory phosphatase PTPN2, by recruitment of the activating phosphatase PTPN1, or by coordinated regulation of both phosphatases (activity and/or substrate access). Further studies are required to define this mechanism and to test whether Src activation might also require engagement of the Src SH3 domain. Indeed, it is possible that the Src-binding protein Sam68 (Fumagalli et al. 1994; Taylor and Shalloway 1994), which acts as an adapter in TNF receptor signaling complexes (Ramakrishnan and Baltimore 2011), links TNF signaling to the Src pathway. Nevertheless, the data reported here demonstrate that TNF can activate Rac by a PTPN1/Src/Vav pathway.

It is established that Rac/Cdc42 can cause MAP kinase activation (Coso et al. 1995; Minden et al. 1995). The effects of Rac/Cdc42 may be mediated by binding to the CRIB motif on MLK3 (Teramoto et al. 1996). We report that the functions of MLK3 are partially redundant with the related protein kinase MLK2 in MEFs (Fig. 1G) and macrophages (Fig. 1H). Compound gene disruption studies demonstrate that $\mathrm{Mlk}^{-1-} \mathrm{Mlk3}^{-/-}$MEFs and macrophages exhibit a severe defect in TNF-stimulated MAP kinase activation (Fig. 1G,H). Moreover, the disrupted MLK CRIB motif in primary cells isolated from $\mathrm{Mlk}^{-/-}$ $M I k 3^{\triangle C R I B / \triangle C R I B}$ mice also caused markedly reduced TNFstimulated MAP kinase activation (Fig. 1I). These data indicate that MLK protein kinases mediate the effects of TNF-stimulated Rac/Cdc42 on MAP kinase activation.

The MLK protein kinases have been implicated in the activation of the NF-kB pathway (Hehner et al. 2000). However, we found no defects in TNF-stimulated IKK $\beta$

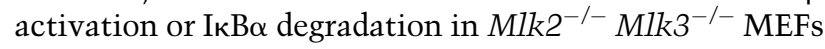
(Fig. 1G). These data indicate that MLK protein kinases are not involved in the TNF-stimulated NF-кB pathway. Studies of Tak1 $1^{-1-}$ MEFs demonstrated that TAK1 deficieincy completely ablated the TNF-stimulated NF-кB pathway, but caused only partial loss of TNF-stimulated MAP kinase activation (Fig. 3A). Together, these data indicate that TAK1 plays a key role in TNF-stimulated NF- $\mathrm{B}$ 
Kant et al.

A

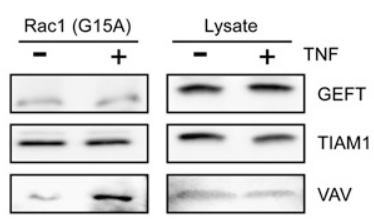

B

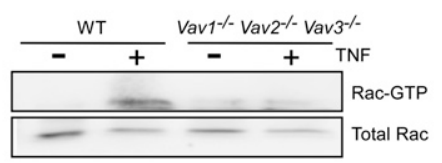

C

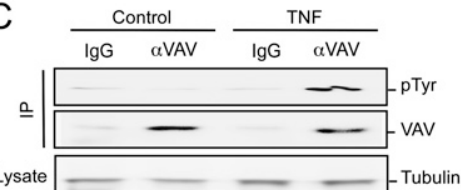

D

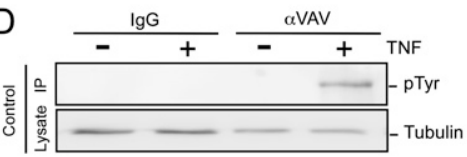

PTubulin
E

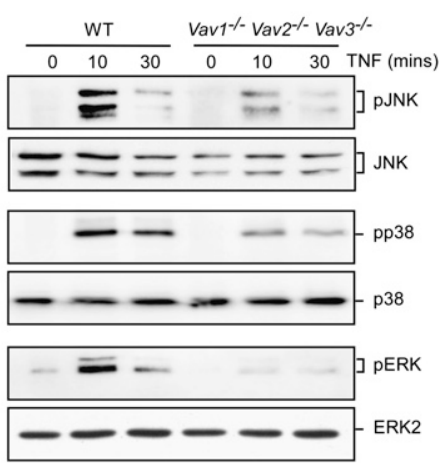

$\mathrm{F}$

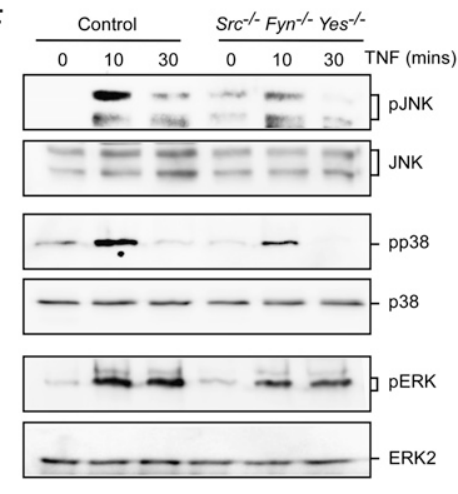

Figure 4. TNF-stimulated Rac activation is mediated by Src and Vav. (A) Lysates prepared from BMDMs treated without or with $10 \mathrm{ng} / \mathrm{mL}$ TNF $(15$ $\mathrm{min})$ were incubated with immobilized Rac1 ${ }^{\mathrm{G} 15 \mathrm{~A}}$. Bound proteins and the cell lysates were examined by immunoblot analysis using antibodies to GEFT, TIAM1, and Vav. (B) Wild-type (WT) and Vav1 $1^{-1-}$ Vav2 $^{-/-} \mathrm{Vav3}^{-/-}$BMDMs were treated without or with $10 \mathrm{ng} / \mathrm{mL}$ TNF $\alpha$. Activated (GTP-loaded) Rac was isolated and quantitated by immunoblot analysis. The amount of Rac in cell lysates was measured by immunoblot analysis. $(C)$ Lysates prepared from wild-type BMDMs treated without or with TNF were examined by immunoprecipitation with a control antibody (IgG) or with an antibody to Vav. The immunoprecipitates were examined by immunoblot analysis using antibodies to phosphotyrosine (pTyr) and Vav. The cell lysates were examined by probing with an antibody to $\alpha$-Tubulin. (D) $\mathrm{Src}^{-/-} \mathrm{Fyn}^{--}$ $\mathrm{Yes}^{-/-}$fibroblasts complemented with Src (Control) or without Src were treated without or with TNF $\alpha$. Lysates were examined by immunoprecipitation with a control antibody $(\mathrm{IgG})$ or with an antibody to Vav. The immunoprecipitates were examined by immunoblot analysis using antibodies to pTyr. The cell lysates were examined by probing with an antibody to $\alpha$-Tubulin. $(E, F)$ Wild-type and $\operatorname{Vav1}^{-/-} \operatorname{Vav}^{-/-}$ Vav3 $3^{-/-}$BMDMs $(E)$ or Control and $\mathrm{Src}^{-/-} \mathrm{Fyn}^{-/-}$ $\mathrm{Yes}^{-1-}$ fibroblasts $(F)$ were treated without or with 10 $\mathrm{ng} / \mathrm{mL}$ TNF. MAP kinase activation was examined by immunoblot analysis. activation and that both TAK1 and MLK protein kinases contribute to TNF-stimulated MAP kinase activation.

The TAK1 and MLK pathways represent different signaling mechanisms employed by TNF receptor 1 . Both of these pathways provide an opportunity for therapeutic intervention that may be useful for the treatment of human inflammatory diseases. However, the effects of inhibition of these pathways are different because only
A

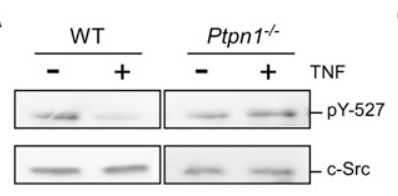

B

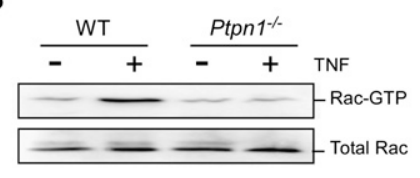

C
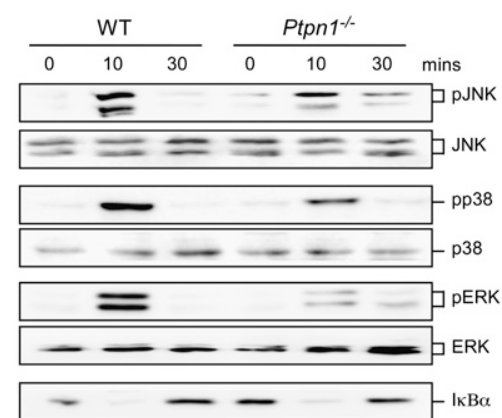

D

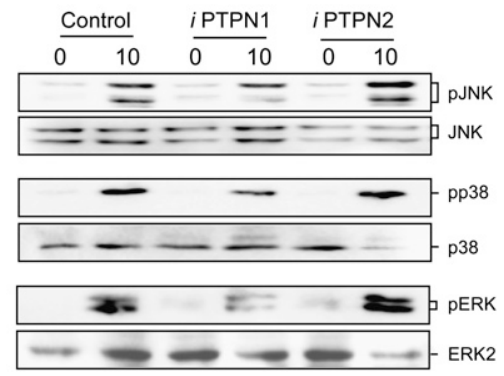

Figure 5. The protein tyrosine phosphatase PTPN1 contributes to TNF-stimulated MAP kinase activation. (A) Lysates prepared from wild-type (WT) and Ptpn1 ${ }^{-/-}$ BMDMs were treated without or with $10 \mathrm{ng} / \mathrm{mL}$ TNF $\alpha$ and examined by immunoblot analysis using antibodies to Src and $\mathrm{pY}^{527}$ Src. (B) Wild-type and Ptpn $1^{-/-}$BMDMs were treated without or with $10 \mathrm{ng} / \mathrm{mL}$ TNF (15 min). Activated (GTP-loaded) Racl was isolated and quantitated by immunoblot analysis. The amount of Racl in cell lysates was measured by immunoblot analysis. $(C)$ Wild-type and Ptpn $1^{-1-}$ BMDMs were treated without or with $10 \mathrm{ng} / \mathrm{mL}$ TNF. MAP kinase activation and the degradation of ІкB $\alpha$ was examined by immunoblot analysis. $(D)$ BMDMs were treated with solvent or with drugs that selectively inhibit PTPN1 and PTPN2 (30 $\mathrm{min})$. The cells were then treated with or without $10 \mathrm{ng} / \mathrm{mL}$ $\mathrm{TNF} \alpha(10 \mathrm{~min})$. Cell lysates were examined by immunoblot analysis using antibodies to phospho-JNK, JNK, phosphop38, p38 $\alpha$, phospho-ERK, and ERK2. 
A

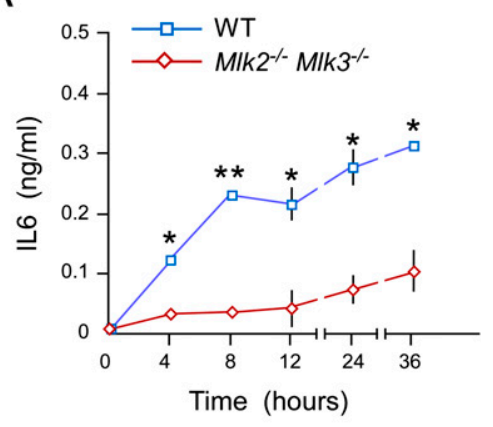

B
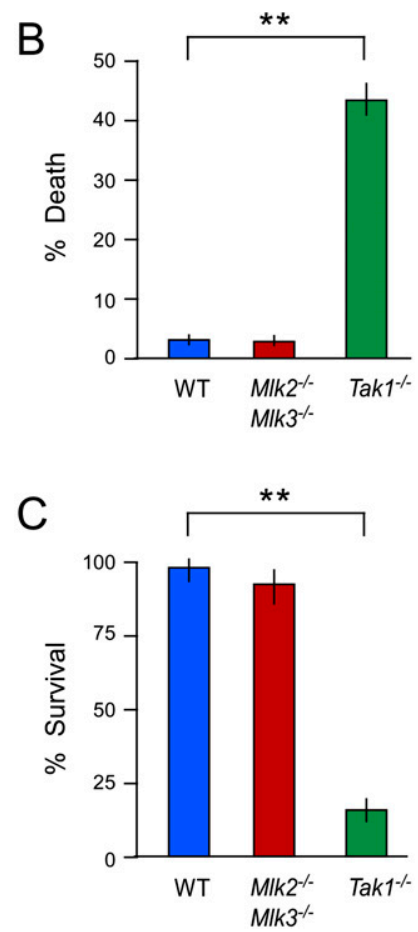

Figure 6. The MLK pathway contributes to TNF-stimulated

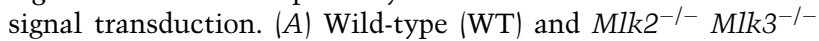
MEFs were treated with $10 \mathrm{ng} / \mathrm{mL}$ TNF $\alpha$. The amount of IL6 in the culture medium was measured by ELISA (mean $\pm \mathrm{SD} ; n=6$ ). Statistically significant differences between wild-type and $M l k 2^{-/-}$ $M l k 3^{-l-}$ MEFs are indicated. $\left(^{\star}\right) P<0.05$; $\left(^{\star \star}\right) P<0.01$. $(B, C)$ Wild-

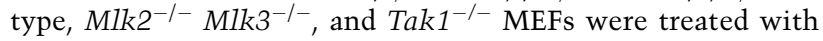
$10 \mathrm{ng} / \mathrm{mL}$ TNF $(24 \mathrm{~h})$. Cell death was examined by measuring the presence of lactate dehydrogenase in the medium $(B)$, and cell viability was measured by staining with crystal violet $(C)$. The data presented are the mean $\pm \operatorname{SD}(n=4)$. Statistically significant differences between wild-type and Tak1 $1^{-1-}$ MEFs are indicated. $\left(^{\star \star}\right) P<0.01$. No statistically significant differences

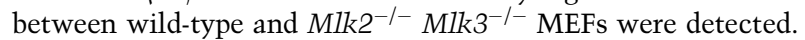

TAK1 inhibition causes decreased NF-кB-mediated survival signaling (Fig. 6B,C). The reduced TNF-mediated cytotoxicity caused by loss of MLK function, compared with loss of TAK1 function, may be a beneficial property of drugs that target MLK to inhibit TNF-stimulated inflammatory cytokine expression during disease progression in humans.

\section{Materials and methods}

Mice

C57BL/6J strain mice were obtained from The Jackson Laboratories. Mice with Mlk3 (Brancho et al. 2005), Ptpn1 (Klaman et al. 2000), Tak1 (Shim et al. 2005), or Vav1, Vav2, and Vav3 (Fujikawa et al. 2003) gene disruptions have been described previously.

Mice with germline mutations in exon VII of the Mlk3 gene $\left(M I k 3^{\Delta C R I B}\right)$ were constructed using homologous recombination in LC1 embryonic stem (ES) cells (albino C57BL/6J genetic background). The targeting vector was constructed using a mouse strain C57BL/6J genomic BAC clone containing the Mlk3 gene, a floxed $N e o^{R}$ cassette, and a thymidine kinase cassette (Fig. 1C). The ES cells were electroporated and selected with $200 \mu \mathrm{g} / \mathrm{mL}$ G418 and $2 \mu \mathrm{M}$ gangcyclovir. Correctly targeted ES cell clones were injected into C57BL/6J blastocysts to create chimeric mice that transmitted the mutated MIk3 allele through the germline. The floxed $\mathrm{NeO}^{R}$ cassette was excised using Cre recombinase.

$M l k 2^{-/-}$gene disruption by homologous recombination using $129 / \mathrm{Sv}$ J strain ES cells was used to create a deletion (exon I to exon VI) within the Mlk2 gene (Supplemental Fig. S2). Correctly targeted ES cell clones were employed to create chimeric mice that transmitted the mutated Mlk2 allele through the germline (D.S. Dorow, Peter MacCallum Cancer Institute). The Mlk2-1mice were backcrossed to the C57BL/6J strain (10 generations).

The mice were housed in a facility accredited by the American Association for Laboratory Animal Care. All animal studies were approved by the Institutional Animal Care and Use Committee of the University of Massachusetts Medical School.

\section{Genotype analysis}

Wild-type (500-base-pair [bp]) and disrupted (600-bp) alleles of Mlk2 were detected by PCR using the amplimers 5 '-CCTGG TTCTCACTGGGACAACAG-3' , 5'-GTCACATCCACTTTCC TGGGC-3' , and 5'-CGCCTTCTATCGCCTTCTTGAC-3'. Wildtype and disrupted alleles of Mlk3 (Brancho et al. 2005), Ptpn1 (Klaman et al. 2000), Tak1 (Shim et al. 2005), or Vav1/2/3 (Fujikawa et al. 2003) were detected by PCR analysis using genomic DNA as the template. The Mlk $3^{\Delta C R I B}$ allele (160 bp) was detected by PCR amplification of genomic DNA using the amplimers 5'-CCCAACCCCAAAATAAGC-3', and 5'-CGGAGAACGCA TCAGC-3'; the corresponding wild-type allele (160 bp) was detected using the amplimers 5'-CCCAACCCCAAAATAAGC-3' and $5^{\prime}$-CGGAGAACGCGCAGCC-3'.

\section{Cell culture}

BMDMs were prepared (Das et al. 2009) and cultured in Dulbecco's modified Eagle's medium supplemented with 30\% L929 supernatant (source of M-CSF), 20\% fetal bovine serum, $100 \mathrm{U} / \mathrm{mL}$ penicillin, $100 \mu \mathrm{g} / \mathrm{mL}$ streptomycin, and $2 \mathrm{mM} \mathrm{L}$-glutamine (Invitrogen).

$\mathrm{Src}^{-/-} \mathrm{Fyn}^{-/-} \mathrm{Yes}^{-/-}$fibroblasts complemented without and with Src (Klinghoffer et al. 1999) were obtained from the American Type Culture Collection (no. CRL2459 and no. CRL2498) and were cultured in Dulbecco's modified Eagle's medium supplemented with $10 \%$ fetal bovine serum, $100 \mathrm{U} / \mathrm{mL}$ penicillin, 100 $\mu \mathrm{g} / \mathrm{mL}$ streptomycin, and $2 \mathrm{mM}$ L-glutamine (Invitrogen).

Embryonic day 13.5 (E13.5) primary MEFs were cultured in Dulbecco's modified Eagle's medium supplemented with $10 \%$ fetal bovine serum, $100 \mathrm{U} / \mathrm{mL}$ penicillin, $100 \mu \mathrm{g} / \mathrm{mL}$ streptomycin, and $2 \mathrm{mM}$ L-glutamine (Invitrogen). Retroviral transduction assays (Lamb et al. 2003) were performed using the vectors pBABE-puro and pBABE-Rac1 ${ }^{\mathrm{Q} 61 \mathrm{~L}}$-puro. Transfection assays were performed 


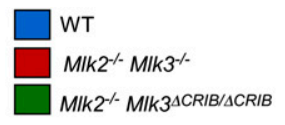

A
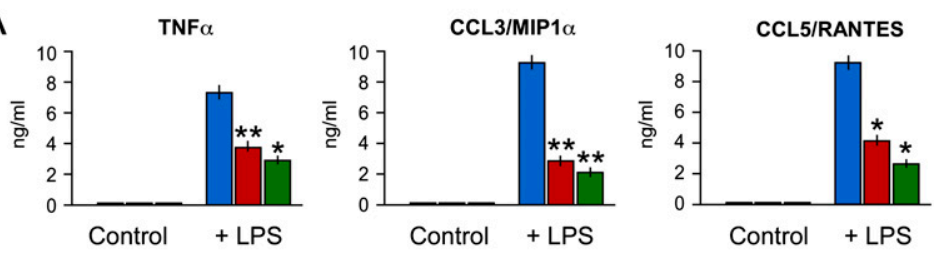

B
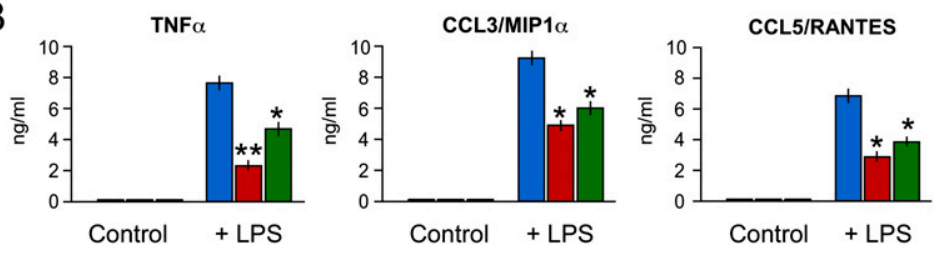

Figure 7. The MLK pathway contributes to LPSmediated inflammation. (A) Wild-type (WT) mice, $\mathrm{Mlk}^{-{ }^{--}}$ $M l k 3^{-I-}$ mice, and Mlk $2^{-I-} M l k 3^{\Delta \mathrm{CRIB} / \Delta \mathrm{CRIB}}$ mice were treated without and with $20 \mathrm{mg} / \mathrm{kg}$ LPS by intraperitoneal injection $(2 \mathrm{~h})$. The amount of $\mathrm{TNF} \alpha, \mathrm{CCL} 3 / \mathrm{MIP} \alpha$, and CCL5/RANTES in the serum was measured by ELISA (mean $\pm \mathrm{SD} ; n=8$ ). Statistically significant differences between wild-type and MLK-deficient mice are indicated. $\left(^{\star}\right) P<0.05 ;\left(^{\star \star}\right) P<0.01$. $(B)$ Primary BMDMs were isolated from wild-type mice, Mlk2 $2^{-1-}$

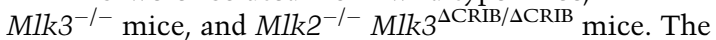
BMDMs were treated without and with $100 \mathrm{ng} / \mathrm{mL}$ LPS (24 h). The amount of TNF $\alpha$, CCL3/MIP $\alpha$, and CCL5/ RANTES in the culture medium was measured by ELISA (mean $\pm S D ; n=6$ ). Statistically significant differences between wild-type and MLK-deficient BMDMs are indicated. $\left(^{\star}\right) P<0.05$ ( $\left.^{\star \star}\right) P<0.01$. using DharmaFECT 3 reagent with ON-TARGET plus Nontargeting Pool D-001810-10 for control or ON-TARGET plus SMART pool L-040718-00 for Tak1 (MAP3K7) siRNA (Thermo Scientific). Single siRNA for Tak1 were ON-TARGET plus siRNA J-04071807 and ON-TARGET plus siRNA J-040718-08. Cells were harvested at $72 \mathrm{~h}$ post-transfection. Proliferation assays and cell viability assays were performed by staining cells with crystal violet (Tournier et al. 2000). Cell death was examined by measurement of lactate dehydrogenase release using a Cytotoxicity Detection kit (Roche Applied Science).

The cells were treated with $10 \mathrm{ng} / \mathrm{mL}$ TNF $\alpha$ (R\&D Systems) or $100 \mathrm{ng} / \mathrm{mL}$ LPS (Sigma). The cells were pretreated (30 min) without or with an inhibitor of PTPN1 (200 nM) or PTPN2 (20 nM) (Sun et al. 2003; Zhang et al. 2009).

\section{RNA analysis}

The expression of mRNA was examined by quantitative PCR analysis using a 7500 Fast Real-Time PCR machine (Applied Biosystems). TaqMan assays were used to quantitate Mlk1 (Mm00616834_m1), Mlk2 (Mm01175535_m1), Mlk3 (Mm01233534_m1), Mlk4 (Mm00524049_m1), Tak1 (Mm00554514_m1), Tnfr1 (Mm01182929_m1), Tnfr2 (Mm00441889_m1), and Gapdh (4352339E-0904021) mRNA (Applied Biosystems). Standard curves were constructed using the threshold cycle $(\mathrm{Ct})$ values for each template dilution plotted as a function of the logarithm of the amount of input template. The number of mRNA copies for each gene sample combination was calculated using the slope of the standard curve. To obtain a normalized abundance, copy numbers were corrected for the amount of Gapdh mRNA in each sample.

\section{Immunoblot analysis}

Cell extracts were prepared using Triton lysis buffer $(20 \mathrm{mM}$ Tris at $\mathrm{pH} 7.4,1 \%$ Triton X-100, $10 \%$ glycerol, $137 \mathrm{mM} \mathrm{NaCl}, 2 \mathrm{mM}$ EDTA, $25 \mathrm{mM} \beta$-glycerophosphate, $1 \mathrm{mM}$ sodium orthovanadate, $1 \mathrm{mM}$ phenylmethylsulfonyl fluoride, $10 \mu \mathrm{g} / \mathrm{mL}$ aprotinin and leupeptin). The lysates (50 $\mu \mathrm{g}$ of protein) were examined by protein immunoblot analysis. Immunecomplexes were detected by enhanced chemiluminescence (NEN). Primary antibodies were obtained from Cell Signaling $(\mathrm{Cdc} 42$, phospho-IKK $\beta$, IKK $\beta$,
MLK3, phospho-ERK1/2, phospho-JNK1/2, p38 $\alpha$, phospho-p38, Src, $\mathrm{pY}^{527}$-Src, Vav1/2/3, Rac1/2/3, and IкB $\alpha$ ), BD Pharmingen (JNK1/2), Millipore (Rac1, Vav, and phosphotyrosine), Santa Cruz Biotechnologies (ERK2, TAK1, and TIAM1), Sigma ( $\alpha$-Tubulin), and Proteintech Group (GEFT). The polyclonal antibody to MLK2 was purified from serum obtained from rabbits immunized with a peptide that corresponds to MLK2 amino acids 898-911 (CISPPSRPDTPESPG-amide) conjugated to keyhole limpet hemocyanin (Yenzym).

\section{Immunoprecipitation}

Cell extracts were prepared using lysis buffer ( $150 \mathrm{mM} \mathrm{NaCl}, 50$ $\mathrm{mM}$ Tris at $\mathrm{pH}$ 8.0, $5 \mathrm{mM}$ EDTA, 1\% NP-40, $1 \mathrm{mM} \mathrm{PMSF)} \mathrm{and}$ incubated $\left(5 \mathrm{~h}\right.$ at $\left.4^{\circ} \mathrm{C}\right)$ with $10 \mu \mathrm{g}$ of control nonimmune rabbit IgG (Santa Cruz Biotechnologies) or $10 \mu \mathrm{g}$ of rabbit antibodies to Vav (Millipore) and Vav1/2/3 (Cell Signaling). Immunecomplexes isolated using Protein G Sepharose were washed (five times) with lysis buffer.

\section{Cytokine and chemokine analysis}

Cytokines in cell culture medium were measured by multiplexed ELISA using a Luminex 200 machine (Millipore) and a serum mouse cytokine kit (Millipore).

\section{Rac/Cdc42 activation}

Assays were performed with the Rac/Cdc42 Activation Assay kit using the manufacturer's recommendations (Millipore). Cdc42 was detected by immunoblot analysis (Cell Signaling). Rac was detected by immunoblot analysis using an antibody to Rac1 (Millipore) for studies of MEFs and an antibody to Rac1/2/3 (Cell Signaling) for BMDM studies.

\section{Analysis of RhoGEF proteins}

TNF-activated RhoGEFs were identified by affinity chromatography using a nucleotide-free transition state mimic of Rac1 (GarciaMata et al. 2006). Cell extracts prepared using lysis buffer $(150 \mathrm{mM}$ $\mathrm{NaCl}, 50 \mathrm{mM}$ Tris at $\mathrm{pH}$ 8.0, $5 \mathrm{mM}$ EDTA, 1\% NP-40, $1 \mathrm{mM}$ PMSF) were incubated with GST-Rac1 ${ }^{\text {G15A }}$ immobilized on 
GSH-Sepharose for $1 \mathrm{~h}$ at $4^{\circ} \mathrm{C}$. The GSH-Sepharose was washed, and bound proteins were examined by immunoblot analysis.

\section{Acknowledgments}

We thank S. Ghosh and D.S. Dorow for providing mice; K. Burridge and J.S. Gutkind for plasmids; R. Kaushik, N. Kennedy, C. Morel, G. Sabio, C. Standen, and A. Vertii for advice; V. Benoit, L. Lesco, J. Reilly, H.-F. Hung, and T. Barrett for technical assistance; and K. Gemme for administrative assistance. These studies were supported by grants from the National Institutes of Health (CA065861 to R.J.D., AI06107 to W.S., and CA126937 to Z.-Y.Z.). Core facilities at the University of Massachusetts used by this study were supported by the NIDDK Diabetes and Endocrinology Research Center (DK52530). W.S. is a Scholar of the Leukemia and Lymphoma Society. R.J.D. and R.A.F are Investigators of the Howard Hughes Medical Institute.

\section{References}

Abe K, Rossman KL, Liu B, Ritola KD, Chiang D, Campbell SL, Burridge K, Der CJ. 2000. Vav2 is an activator of Cdc42, Rac1, and RhoA. J Biol Chem 275: 10141-10149.

Bock BC, Vacratsis PO, Qamirani E, Gallo KA. 2000. Cdc42induced activation of the mixed-lineage kinase SPRK in vivo. Requirement of the Cdc42/Rac interactive binding motif and changes in phosphorylation. J Biol Chem 275: 14231-14241.

Brancho D, Tanaka N, Jaeschke A, Ventura JJ, Kelkar N, Tanaka Y, Kyuuma M, Takeshita T, Flavell RA, Davis RJ. 2003. Mechanism of p38 MAP kinase activation in vivo. Genes Dev 17: 1969-1978.

Brancho D, Ventura JJ, Jaeschke A, Doran B, Flavell RA, Davis RJ. 2005. Role of MLK3 in the regulation of mitogenactivated protein kinase signaling cascades. Mol Cell Biol 25: 3670-3681.

Chadee DN, Kyriakis JM. 2004. MLK3 is required for mitogen activation of B-Raf, ERK and cell proliferation. Nat Cell Biol 6: 770-776.

Coso OA, Chiariello M, Yu JC, Teramoto H, Crespo P, Xu N, Miki T, Gutkind JS. 1995. The small GTP-binding proteins Rac1 and Cdc42 regulate the activity of the JNK/SAPK signaling pathway. Cell 81: 1137-1146.

Crespo P, Schuebel KE, Ostrom AA, Gutkind JS, Bustelo XR. 1997. Phosphotyrosine-dependent activation of Rac-1 GDP/ GTP exchange by the vav proto-oncogene product. Nature 385: 169-172.

Das S, Cho J, Lambertz I, Kelliher MA, Eliopoulos AG, Du K, Tsichlis PN. 2005. Tpl2/cot signals activate ERK, JNK, and NF- $\mathrm{B}$ in a cell-type and stimulus-specific manner. I Biol Chem 280: 23748-23757.

Das M, Sabio G, Jiang F, Rincon M, Flavell RA, Davis RJ. 2009. Induction of hepatitis by JNK-mediated expression of TNF- $\alpha$. Cell 136: 249-260.

Feldmann M. 2002. Development of anti-TNF therapy for rheumatoid arthritis. Nat Rev Immunol 2: 364-371.

Fujikawa K, Miletic AV, Alt FW, Faccio R, Brown T, Hoog J, Fredericks J, Nishi S, Mildiner S, Moores SL, et al. 2003. Vav1/2/3-null mice define an essential role for Vav family proteins in lymphocyte development and activation but a differential requirement in MAPK signaling in $\mathrm{T}$ and $\mathrm{B}$ cells. J Exp Med 198: 1595-1608.

Fumagalli S, Totty NF, Hsuan JJ, Courtneidge SA. 1994. A target for Src in mitosis. Nature 368: 871-874.

Garcia-Mata R, Wennerberg K, Arthur WT, Noren NK, Ellerbroek SM, Burridge K. 2006. Analysis of activated GAPs and GEFs in cell lysates. Methods Enzymol 406: 425-437.
Han J, Das B, Wei W, Van Aelst L, Mosteller RD, Khosravi-Far R, Westwick JK, Der CJ, Broek D. 1997. Lck regulates Vav activation of members of the Rho family of GTPases. Mol Cell Biol 17: 1346-1353.

Hanna AN, Berthiaume LG, Kikuchi Y, Begg D, Bourgoin S, Brindley DN. 2001. Tumor necrosis factor- $\alpha$ induces stress fiber formation through ceramide production: role of sphingosine kinase. Mol Biol Cell 12: 3618-3630.

Hehner SP, Hofmann TG, Ushmorov A, Dienz O, Wing-Lan Leung I, Lassam N, Scheidereit C, Droge W, Schmitz ML. 2000. Mixed-lineage kinase 3 delivers CD3/CD28-derived signals into the IкB kinase complex. Mol Cell Biol 20: 25562568.

Ichijo H, Nishida E, Irie K, ten Dijke P, Saitoh M, Moriguchi T, Takagi M, Matsumoto K, Miyazono K, Gotoh Y. 1997. Induction of apoptosis by ASK1, a mammalian MAPKKK that activates SAPK/JNK and p38 signaling pathways. Science 275: 90-94.

Karin M. 2005. Inflammation-activated protein kinases as targets for drug development. Proc Am Thorac Soc 2: 386390.

Kim BC, Lee MN, Kim JY, Lee SS, Chang JD, Kim SS, Lee SY, Kim JH. 1999. Roles of phosphatidylinositol 3-kinase and Rac in the nuclear signaling by tumor necrosis factor- $\alpha$ in rat-2 fibroblasts. J Biol Chem 274: 24372-24377.

Kim SH, Kim J, Sharma RP. 2004. Inhibition of p38 and ERK MAP kinases blocks endotoxin-induced nitric oxide production and differentially modulates cytokine expression. Pharmacol Res 49: 433-439.

Kim YS, Morgan MJ, Choksi S, Liu ZG. 2007. TNF-induced activation of the Nox1 NADPH oxidase and its role in the induction of necrotic cell death. Mol Cell 26: 675-687.

Klaman LD, Boss O, Peroni OD, Kim JK, Martino JL, Zabolotny JM, Moghal N, Lubkin M, Kim YB, Sharpe AH, et al. 2000. Increased energy expenditure, decreased adiposity, and tissue-specific insulin sensitivity in protein-tyrosine phosphatase 1B-deficient mice. Mol Cell Biol 20: 5479-5489.

Klinghoffer RA, Sachsenmaier C, Cooper JA, Soriano P. 1999. Src family kinases are required for integrin but not PDGFR signal transduction. EMBO J 18: 2459-2471.

Korchnak AC, Zhan Y, Aguilar MT, Chadee DN. 2009. Cytokine-induced activation of mixed lineage kinase 3 requires TRAF2 and TRAF6. Cell Signal 21: 1620-1625.

Lamb JA, Ventura JJ, Hess P, Flavell RA, Davis RJ. 2003. JunD mediates survival signaling by the JNK signal transduction pathway. Mol Cell 11: 1479-1489.

Liu BP, Burridge K. 2000. Vav2 activates Rac1, Cdc42, and RhoA downstream from growth factor receptors but not $\beta 1$ integrins. Mol Cell Biol 20: 7160-7169.

Micheau O, Tschopp J. 2003. Induction of TNF receptor I-mediated apoptosis via two sequential signaling complexes. Cell 114: 181-190.

Minden A, Lin A, Claret FX, Abo A, Karin M. 1995. Selective activation of the JNK signaling cascade and c-Jun transcriptional activity by the small GTPases Rac and Cdc42Hs. Cell 81: 1147-1157.

Nishitoh H, Saitoh M, Mochida Y, Takeda K, Nakano H, Rothe M, Miyazono K, Ichijo H. 1998. ASK1 is essential for JNK/ SAPK activation by TRAF2. Mol Cell 2: 389-395.

Puls A, Eliopoulos AG, Nobes CD, Bridges T, Young LS, Hall A. 1999. Activation of the small GTPase Cdc42 by the inflammatory cytokines TNF $\alpha$ and IL-1, and by the Epstein-Barr virus transforming protein LMP1. J Cell Sci 112: 2983-2992.

Ramakrishnan P, Baltimore D. 2011. Sam68 is required for both NF- $\kappa \mathrm{B}$ activation and apoptosis signaling by the TNF receptor. Mol Cell 43: 167-179. 
Kant et al.

Robinson MJ, Cobb MH. 1997. Mitogen-activated protein kinase pathways. Curr Opin Cell Biol 9: 180-186.

Sathyanarayana P, Barthwal MK, Kundu CN, Lane ME, Bergmann A, Tzivion G, Rana A. 2002. Activation of the Drosophila MLK by ceramide reveals TNF- $\alpha$ and ceramide as agonists of mammalian MLK3. Mol Cell 10: 1527-1533.

Sato S, Sanjo H, Takeda K, Ninomiya-Tsuji J, Yamamoto $M$, Kawai T, Matsumoto K, Takeuchi O, Akira S. 2005. Essential function for the kinase TAK1 in innate and adaptive immune responses. Nat Immunol 6: 1087-1095.

Shim JH, Xiao C, Paschal AE, Bailey ST, Rao P, Hayden MS, Lee KY, Bussey C, Steckel M, Tanaka N, et al. 2005. TAK1, but not TAB1 or TAB2, plays an essential role in multiple signaling pathways in vivo. Genes Dev 19: 2668-2681.

Skaug B, Jiang X, Chen ZJ. 2009. The role of ubiquitin in NF-кB regulatory pathways. Annu Rev Biochem 78: 769-796.

Sondarva G, Kundu CN, Mehrotra S, Mishra R, Rangasamy V, Sathyanarayana P, Ray RS, Rana B, Rana A. 2009. TRAF2MLK3 interaction is essential for TNF- $\alpha$-induced MLK3 activation. Cell Res 20: 89-98.

Song JS, Haleem-Smith H, Arudchandran R, Gomez J, Scott PM, Mill JF, Tan TH, Rivera J. 1999. Tyrosine phosphorylation of Vav stimulates IL-6 production in mast cells by a Rac/c-Jun N-terminal kinase-dependent pathway. J Immunol 163: 802-810.

Sun JP, Fedorov AA, Lee SY, Guo XL, Shen K, Lawrence DS, Almo SC, Zhang ZY. 2003. Crystal structure of PTP1B complexed with a potent and selective bidentate inhibitor. J Biol Chem 278: 12406-12414.

Swat W, Fujikawa K. 2005. The Vav family: at the crossroads of signaling pathways. Immunol Res 32: 259-265.

Taylor SJ, Shalloway D. 1994. An RNA-binding protein associated with Src through its $\mathrm{SH} 2$ and $\mathrm{SH} 3$ domains in mitosis. Nature 368: 867-871.

Teramoto H, Coso OA, Miyata H, Igishi T, Miki T, Gutkind JS. 1996. Signaling from the small GTP-binding proteins Racl and $\mathrm{Cdc} 42$ to the c-Jun $\mathrm{N}$-terminal kinase/stress-activated protein kinase pathway. A role for mixed lineage kinase 3/protein-tyrosine kinase 1, a novel member of the mixed lineage kinase family. J Biol Chem 271: 27225-27228.

Tobiume K, Matsuzawa A, Takahashi T, Nishitoh H, Morita K, Takeda K, Minowa O, Miyazono K, Noda T, Ichijo H. 2001. ASK1 is required for sustained activations of JNK/p38 MAP kinases and apoptosis. EMBO Rep 2: 222-228.

Tournier C, Hess P, Yang DD, Xu J, Turner TK, Nimnual A, BarSagi D, Jones SN, Flavell RA, Davis RJ. 2000. Requirement of JNK for stress-induced activation of the cytochrome $c$-mediated death pathway. Science 288: 870-874.

Tournier C, Dong C, Turner TK, Jones SN, Flavell RA, Davis RJ. 2001. MKK7 is an essential component of the JNK signal transduction pathway activated by proinflammatory cytokines. Genes Dev 15: 1419-1426.

Tuyt LM, Dokter WH, Birkenkamp K, Koopmans SB, Lummen C, Kruijer W, Vellenga E. 1999. Extracellular-regulated kinase $1 / 2$, Jun $\mathrm{N}$-terminal kinase, and c-Jun are involved in NF-к B-dependent IL-6 expression in human monocytes. I Immunol 162: 4893-4902.

van Vliet C, Bukczynska PE, Puryer MA, Sadek CM, Shields BJ, Tremblay ML, Tiganis T. 2005. Selective regulation of tumor necrosis factor-induced Erk signaling by Src family kinases and the T cell protein tyrosine phosphatase. Nat Immunol 6: 253-260.

Ventura JJ, Hubner A, Zhang C, Flavell RA, Shokat KM, Davis RJ. 2006. Chemical genetic analysis of the time course of signal transduction by JNK. Mol Cell 21: 701-710.

Wojciak-Stothard B, Entwistle A, Garg R, Ridley AJ. 1998. Regulation of TNF- $\alpha$-induced reorganization of the actin cytoskeleton and cell-cell junctions by Rho, Rac, and Cdc42 in human endothelial cells. J Cell Physiol 176: 150165.

Xia Y, Makris C, Su B, Li E, Yang J, Nemerow GR, Karin M. 2000. MEK kinase 1 is critically required for c-Jun $\mathrm{N}$-terminal kinase activation by proinflammatory stimuli and growth factor-induced cell migration. Proc Natl Acad Sci 97: 5243-5248.

Yazdanpanah B, Wiegmann K, Tchikov V, Krut O, Pongratz C, Schramm M, Kleinridders A, Wunderlich T, Kashkar $H$, Utermohlen O, et al. 2009. Riboflavin kinase couples TNF receptor 1 to NADPH oxidase. Nature 460: 1159-1163.

Zhang S, Chen L, Luo Y, Gunawan A, Lawrence DS, Zhang ZY. 2009. Acquisition of a potent and selective TC-PTP inhibitor via a stepwise fluorophore-tagged combinatorial synthesis and screening strategy. J Am Chem Soc 131: 13072-13079. 


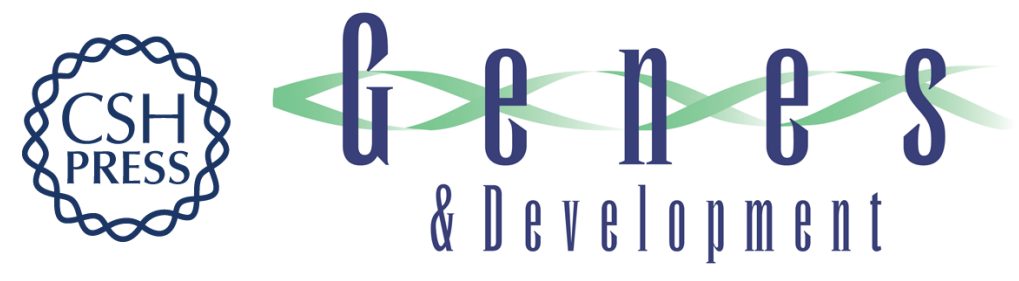

\section{TNF-stimulated MAP kinase activation mediated by a Rho family GTPase signaling pathway}

Shashi Kant, Wojciech Swat, Sheng Zhang, et al.

Genes Dev. 2011, 25:

Access the most recent version at doi:10.1101/gad.17224711

\section{Supplemental http://genesdev.cshlp.org/content/suppl/2011/10/06/25.19.2069.DC1 Material}

References This article cites 52 articles, 24 of which can be accessed free at: http://genesdev.cshlp.org/content/25/19/2069.full.html\#ref-list-1

License Freely available online through the Genes \& Development Open Access option.
Email Alerting Service

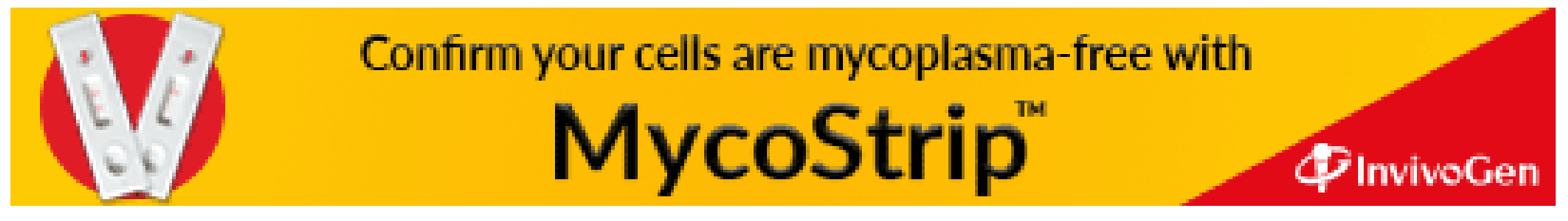

